\title{
ANALISIS PENGARUH MODAL DAN RISIKO TERHADAP KINERJA KEUANGAN BANK MUAMALAT INDONESIA (Studi Kasus Pada PT. Bank Muamalat Indonesia Tbk)
}

\author{
Listian Indriyani Achmad1, Riana Ayu Puspitasari² \\ ${ }^{1}$ STAI Pelita Bangsa, listian.achmad@pelitabangsa.ac.id \\ 2 STAI Pelita Bangsa, rianaayupuspitasari27@gmail.com
}

A R T I C L E I N F O

Article history:

Received : 15/11/2020

Revised : 18/11/2020

Accepted : 19/11/2020

Key words:

Financial performance of Indonesian Muamalat bank, banking capital, banking risk.

DOI:

Doi.org/10.37366/jespb.v5i02.115

\begin{abstract}
A B S T R A C T
This study examines the collapse of net profit and the increase in nonperforming financing or "Non-Performing Financing" due to the wrong funding target carried out by Bank Muamalat Indonesia. This study aims to determine the effect of capital and operational risk on the financial performance of Bank Muamalat Indonesia. Data collection methods in this study are secondary data analysis and literature study. The subjects in this study were Bank Muamalat Indonesia with a total sample size of 30 financial reports. Methods of data analysis in this study using multiple linear regression analysis and classical assumption test. Hypothesis testing is done by using the coefficient of determination ( $R$ and $R$ square), simultaneous significance test (F test), and partial significance test ( $t$ test). The results of the analysis show that capital has a positive regression coefficient value of 0.239 and a significance value of 0.001 (less than 0.05). While the risk has a negative regression coefficient value of -0.087 and a significance value of 0.002 (less than 0.05). Capital has a positive and significant effect on financial performance. The greater the capital a bank has, it shows that the bank is getting stronger and the bank's financial performance will increase. Risk is said to have a negative and significant effect on financial performance. The smaller the risk value faced, the bank's financial performance will increase.
\end{abstract}

\section{A B S T R A K}

Studi ini mengkaji tentang menurunnya laba bersih serta meningkatnya pembiayaan bermasalah atau "Non Performing Financing" akibat salah sasaran pendanaan yang di lakukan oleh Bank Muamalat Indonesia. Penelitian ini bertujuan untuk mengetahui pengaruh modal dan risiko operasional terhadap kinerja keuangan Bank Muamalat Indonesia. Metode pengumpulan data dalam penelitian ini adalah analisis data sekunder dan studi pustaka. Subjek dalam penelitian ialah Bank Muamalat Indonesia dengan jumlah sampel sebanyak 30 laporan keuangan. Metode analisis data dalam penelitian ini menggunakan analisis regresi linier berganda dan uji asumsi klasik. Pengujian hipotesis dilakukan dengan menggunakan uji koefisien determinasi $\left(R^{2}\right)$, uji signifikasi simultan (uji F), dan uji signifikasi parsial (uji t). Hasil analisis menunjukan bahwa modal memiliki nilai koefisien regresi positif sebesar 0,239 dan nilai signifikansi sebesar 0,001 (lebih kecil dari 0,05). Sedangkan risiko memiliki nilai koefisien regresi negatif sebesar -0,087 dan nilai signifikansi sebesar 0,002 (lebih kecil dari 0,05). Modal berpengaruh positif dan signifikan terhadap kinerja keuangan. Semakin besar modal yang dimiliki suatu bank menunjukan bahwa bank tersebut semakin kuat dan kinerja keuangan bank akan meningkat. Risiko dikatakanberpengaruh negatif dan signifikan terhadap kinerja keuangan. Semakin kecil nilai risiko yang dihadapi, maka kinerja keuangan bank akan meningkat. 


\section{PENDAHULUAN}

Berdasarkan olah data dalam laporan Statistik Sistem Keuangan Indonesia (SSKI) pada Maret 2020, yang menggambarkan berbagai perkembangan sektor/elemen yang berperan langsung dalam stabilitas keuangan Indonesia. Dimana indikator yang berperan didalamnya ialah lembaga keuangan/perbankan, institusi keuangan non bank, pasar uang dan pasar modal, pemerintah pusat, korporasi, rumah tangga, properti, infrastruktur keuangan serta keuangan inklusi dan UMKM.

Dalam upaya meningkatkan perekonomian Indonesia, pemerintah sendiri mulai mendirikan perusahaan perbankan sejak memasuki masa kemerdekaan, seperti Bank Negara Indonesia (BNI), Bank Rakyat Indonesia (BRI), Bank Industri Negara (BIN), Bank Tabungan Pos (BTP), serta bank swasta yang telah berdiri seperti bank lumbung desa, bank desa dan yayasan kredit. Sejak awal berdirinya bank-bank di Indonesia memang masih didominasi oleh sistem perbankan yang berbasis konvensial.

Oleh karena itu Majelis Ulama Indonesia (MUI) menyelenggarakan lokakarya bunga bank dan perbankan, yang dilaksanakan pada tanggal 18 - 20 Agustus 1990 di Cisarua, Bogor Jawa Barat. Kemudian disusul pada tanggal 22- 25 Agustus 1990 MUI kembali membahas hasil lokakarya lebih mendalam melalui Musyawarah Nasional (Munas) di Jakarta. Dari hasil musyawarah tersebut terbentuklah kelompok kerja pendirian bank syariah di Indonesia. Yang kemudian melahirkan bank syariah pertama di Indonesia, yang kemudian diberi nama Bank Muamalat Indonesia (BMI) pada 01 November 1991 dengan modal awal sebesar Rp106.126.382.000,- dan resmi beroperasi pada 01
Mei 1992.

Sebagai lembaga yang berperan dalam menghimpun dana dan menyalurkan pembiayaan kepada para nasabah guna memenuhi kegiatan perekonomiannya. Bukan berarti dalam pelaksanaan operasionalnya bank syariah tidak mengalami kendala. Salah satu yang menjadi tolak ukur nya ialah kinerja keuangan pada bank tersebut. Dalam penilaian ini, bukanlah perihal yang sepele, sebab baik calon nasabah, calon investor maupun pengamat perekonomian. Kinerja keuangan dari suatu lembaga seperti bank syariah sangat dipantau. Sebab kinerja keuangan suatu bank dijadikan sebagai penilaian apakah bank tersebut dalam keadaan sehat atau tidak. Profitabilitas dalam pengukuran kinerja keuangan perusahaan umumnya diproksikan dengan Return On Assets (ROA)

Dengan melihat fakta yang ada dilapangan, kini bank syariah pertama di Indonesia ini sedang dirundung masalah yang dibilang cukup emergency. Para kalangan pengamat pasar modal menilai bahwa induk permasalahan yang dialami bank syariah tersebut terjadi karena kesalahan saat menjalankan strategi bisnis perusahaan. Hal ini karena Bank Muamalat Indonesia terlalu fokus pada pembiayaan korporasi yang mengakibatkan pembiayaan bermasalah atau "Non Performing Financing".

Menurunnya laba bersih Bank Muamalat terjadi seiring adanya tekanan terhadap pendapatan utama perusahaan. Tidak hanya laba bersih yang anjlok secara drastis, pendapatan penyaluran dana pun turun sebesar $17 \%$ dari tahun sebelumnya. Yakni dari $\operatorname{Rp} 2,3$ triliun pada periode Januari - Agustus 
2018 turun menjadi Rp 1,9 triliun pada periode Januari - Agustus 2019.

Dengan kondisi kinerja keuangan yang seperti ini, Bank Muamalat dikhawatirkan tidak mampu mengembalikan kondisinya seperti sedia kala. Sebab suntikan dana yang saat ini, dinilai hanya dapat memberi nafas panjang pada keberlangsungan perusahaannya. Dari publikasi laporan bulanan yang diterbitkan oleh PT Bank Muamalat Indonesia, mengalami penurunan serupa pada periode Januari-Agustus 2019, dimana pendapatan bulanan setelah pendistribusian bagi hasil tercatat Rp 415,57 milyar. Dibandingkan pada laporan bulanan yang sama di periode tahun sebelumnya yang mencapai Rp 698,85 milyar dengan kecukupan kerugian penurunan nilai. Dalam mengukur kekucupan modal ini, indikator yang digunakan dalam penelitian ini ialah Capital Adequacy Ratio (CAR).

Selain itu, menurunnya kinerja keuangan Bank Muamalat Indonesia bukan hanya dipengaruhi oleh ambruknya pendapatan dari laba bersih perusahaan. Bank Muamalat Indonesia juga menanggung beban operasional yang besar, hal ini dikarenakan risiko yang dihadapi terkait pendanaan korporasi yang bermasalah.Risiko operasional merupakan risiko yang berhubungan dengan penghimpunan dan penggunaan dana. Dalam mengukur risiko operasional ini, indikator yang dapat digunakan ialah Beban Operasional terhadap Pendapatan Operasional (BOPO). BOPO merupakan persentase perbandingan antara beban operasional dengan pendapatan operasional. Dari data laporan rasio keuangan Bank Muamalat Indonesia yang di publish oleh Otoritas Jasa Keuangan (OJK). Rasio nilai BOPO Bank Muamalat dari tahun 2013 sampai 2020 mencapai angka 99,13 $\%$ atau mendekati $100 \%$. Semakin tinggi rasio BOPO maka akan semakin rendah profitabilitas suatu perusahaan

Dalam menjalankan kegiatan usahanya bank perlu mencadangkan modal yang memadai agar dapat terus beroperasi secara ekonomis dan tidak mengalami kesulitan keuangan. Misalnya dalam mengkover kerugian serta mengatasi keadaan krisis/darurat tanpa memudaratkan kondisi keuangan bank tersebut. Dengan demikian, semakin besar modal yang dimiliki suatu bank maka bank tersebut akan besar kapabilitasnya, dan mampu meredam segala risiko yang kemungkinan terjadi. Sebaliknya, bank yang memiliki permodalan yang sedikit akan mengalami keterbatasan dalam menjalankan usahanya, serta berisiko dalam operasional yang lebih besar pula.

Modal tentunya sangat diperlukan sebagai sarana untuk menyerap kerugian maupun kekuatan untuk ekspansi. Hal ini karena modal bagi perbankan merupakan salah satu landasan yang mampu mempertahankan diri dari kerugian yang timbul. Dalam menentukan strategiksasaran penyaluran terkait pendanaan pun perlu diperhatikan agar risiko yang dihadapi oleh perbankan tidak menjadi ancaman besar. Dengan ini kecukupan modal yang besar tentunya dapat mendongkrak kemampuan bank dalam menghadapi berbagai risiko, serta dapat menjalankan segala kegiatan operasional yang tercermin dari kinerja keuangannya.

\section{KAJIAN TEORI}

Bank Syariah merupakan bagian dari lembaga keuangan dimana kegiatan operasional dan 
produknya berpedoman pada prinsip-prinsip Islam yang berlandaskan Al-Qur'an dan Hadits. Usaha pokok Bank Syariah diantaranya yaitu memberikan pinjaman maupun jasa-jasa lainnya yang diberikan kepada nasabah sesuai dengan syariat Islam.

Pemberlakuan UU No. 10 tahun 1998 tentang perubahan UU No. 7 tahun 1992 perihal perbankan telah memberi kesempatan luas untuk pengembangan jaringan perbankan syariah. Disusul pemberlakuan UU No. 23 tahun 1999 tentang Bank Indonesia, menandaskan bahwa BI mempersiapkan perangkat peraturan dan fasilitas penunjang yang mendukung operasional bank syariah.

Kehadiran bank syariah ditengah pertumbuhan perbankan konvensional menjadikan suatu terobosan alternatif bagi masyarakat yang menginginkan layanan jasa perbankan tanpa harus was-was atas persoalan bunga/ riba. Tujuan pendirian bank syariah ialah untuk menegakan prinsip utama islam dalam sistem ekonomi dalam perbankan, diantaranya:

1. Larangan bunga bank/riba dalam setiap transaksi.

2. Memberlakukan revenue sharing atau profit sharing dalam kegiatan usaha yang diperoleh berdasarkan pendapatan dan keuntungan yang sah.

Memberikan zakat sebagai salah satu instrumen dalam perhitungan pembagian keuntungan dan laporan keuangan (Arifin, 2002: 3).

Selain tujuan dari terbentuknya bank syariah, bank syariah juga memiliki fungsi sebagai lembaga keuangan sama halnya dalam perbankan, diantara nya:

\section{Fungsi Manajer Investasi}

Sebagai alat penghimpunan dana oleh bank syariah, khususnya dana Mudharabah yang bertindak sebagai manajer investasi dari pemilik dana (Shahibul Maal). Kemudian dana tersebut harus dapat disalurkan kepada penyalur yang produktif (mudharib), sehingga dana yang dihimpun dapat bermanfaat dan memperoleh keuntungan yang kemudian keunttungan tersebut dapat dibagikan sesuai nisbah (perbandingan) antara shahibul maal dan mudharib/pihak bank dengan nasabahnya.

\section{Fungsi Investor}

Fungsi ini memberikan peran pada bank syariah sebagai investor (pemilik dana). Dalam menginvestasikan dananya bank syariah harus dilakukan pada sektor-sektor yang produktif dengan resiko minim dan tidak bertentangan dengan ketentuan syariah yang berlaku.

\section{Fungsi Sosial}

Fungsi ini memberikan peran pada bank syariah sebagai investor (pemilik dana). Dalam menginvestasikan dananya bank syariah harus dilakukan pada sektor-sektor yang produktif dengan resiko minim dan tidak bertentangan dengan ketentuan syariah yang berlaku.

Dalam menjalankan fungsi sosialnya, bank syariah memiliki ada 2 instrumen, yaitu: Instrumen zakat, infaq, sedekah serta wakaf (ziswaf) dan Instrumen Qaradhul Hasan yang berfungsi menghimpun dana dari penerimaan yang tidak memenuhi kriteria halal serta dana infaq/sedekah. 


\section{Fungsi Jasa Keuangan}

Memberikan layanan kliring, transfer, inkaso, pembayaran gaji, letter of guarantee, dan letter of credit.

Modal dalam perkembangannya ditekankan pada nilai, daya beli atau kekuasaan dalam memakai maupun menggunakan yang terkandung dalam barang-barang. Dengan demikian modal berarti hasil produksi yang digunakan untuk memproduksi lebih lanjut (Bambang Riyanto, 1998: 10).

Modal merupakan faktor produksi yang mempunyai pengaruh kuat dalam mendapatkan produktivitas atau output, secara makro modal merupakan pendorong besar untuk meningkatkan investasi baik secara langsung pada proses produksi maupun dalam prasarana produksi, sehingga mampu mendorong kenaikan produktivitas dan output.

Beberapa hal yang merupakan hal penting dalam modal dalam membantu memproduksi barang maupun jasanya yang akan dibutuhkan manusia dengan tujuan untuk memperoleh keuntungan, antara lain:

- Mempermudah pendirian suatu perusahaan.

- Membantu perkembangan perusahaan, sebab perusahaan yang sedang mengadakan ekspansi membutuhkan modal yang besar. Dan modal ini tak selalu tersedia secara cukup. Sehingga modal ventura dapat mengatasi kesulitan dengan keikutsertaannya dalam permodalan perusahaan.

- Meningkatkan investasi. Dalam sebuah ekonomi yang sedang berkembang sangat dibutuhkan investasi.
- Memperlancar ahli tekhnologi. Tekhnologi yang dimiliki perusahaan belum tentu tekhnolohi yang terbaik, sementara untuk memperoleh tekhnologi yang terbaik tersebut dibutuhkan dana yang cukup besar.

Ada beberapa faktor yang dapat memengaruhi Struktur Modal antara lain struktur aktiva atau tangibility, growth opportunity, ukuran perusahaan, profitabilitas, dan resiko bisnis. Berikut adalah masing-masing penjelasannya:

1) Struktur Aktiva (Tangibility)

2) Growth Opportunity

3) Ukuran Perusahaan (Firm Size)

4) Profitabilitas

5) Risiko Bisnis

Berdasarkan PBI Nomor 13/23/PBI/2011 tentang Penerapan Manajemen Risiko bagi Bank Umum Syariah dan Unit Usaha Syariah terdapat beberapa jenis risiko yang dihadapi bank Islam, antara lain:

1) Risiko Kredit

2) Risiko Perubahan Tingkat Bunga

3) Risiko Pasar

4) Risiko Likuiditas

5) Risiko Operasional

6) Risiko Strategik

7) Risiko Kepatuhan

8) Risiko Imbal Hasil

9) Risiko Investasi

Kinerja keuangan merupakan salah satu penilaian kondisi keuangan dan prestasi perusahaan, dengan analisis yang memerlukan beberapa tolak ukur yang digunakan adalah ratio dan indeks, yang menghubungkan dua data 
keuangan antara satu dengan yang lain (Sawir, 2005).

Adapun tujuan dari penilaian kinerja keuangan bagi perusahaan antara lain sebagai berikut:

1) Mengetahui Tingkat Likuiditas

2) Mengetahui Tingkat Solvabilitas

3) Mengetahui Tingkat Rentabilitas

4) Mengetahui Tingkat Stabilitas

Terdapat dua variabel bebas yang dilibatkan dalam penelitian ini, variabel tersebut adalah profitabilitas kinerja keuangan yang diproksikan dengan ROA, permodalan yang diproksikan dengan CAR, risiko operasional yang diproksikan dengan BOPO. Adapun kerangka pikir dari penelitian ini adalah sebagai berikut:

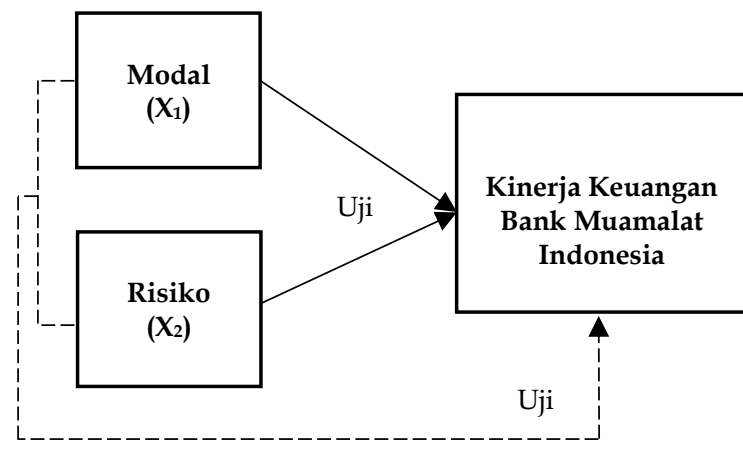

Sumber : Data diolah, 2020

\section{a. Modal $\left(\mathrm{X}_{1}\right)$}

Dari gambar 2. 2 diperoleh hipotesis sebagai berikut:

$\mathrm{H}_{01}$ : Modal tidak berpengaruh signifikan terhadap kinerja keuangan Bank Muamalat Indonesia.

$\mathrm{H}_{\mathrm{a} 1}$ : Modal berpengaruh signifikan terhadap kinerja keuangan Bank Muamalat Indonesia.

$\mathrm{H}_{02}$ : Risiko tidak berpengaruh signifikan terhadap kinerja keuangan Bank Muamalat Indonesia.

$\mathrm{H}_{\mathrm{a} 2}$ : Risiko berpengaruh signifikan terhadap kinerja keuangan Bank Muamalat Indonesia.

$\mathrm{H}_{03}$ : Modal dan risiko tidak berpengaruh signifikan terhadap kinerja keuangan Bank Muamalat Indonesia.
$\mathrm{H}_{\mathrm{a} 3}$ : Modal dan risiko berpengaruh signifikan terhadap kinerja keuangan Bank Muamalat Indonesia.

\section{METODE PENELITIAN}

Penelitian ini dilaksanakan secara terencana dan sistematis guna memperoleh jawaban dalam pemecahan suatu masalah terhadap isu-isu yang menjadi objek penelitian yang telah ditentukan. Sehingga diperolehlah jenis penelitian kuantitatif dengan pendekatan eksplanatori. Dimana salah satu tujuannya yaitu untuk menguji suatu teori atau hipotesis guna memperkuat hasil penelitian sebelumnya yang bersifat mendasar. Pendekatan kuantitatif sesuai dengan pengujian hubungan kausal dari variabel-variabel penelitian yang terukur. Dimana sasaran dari objek penelitiannya yaitu Bank Muamalat Indonesia, yang merupakan perusahaan go public namun tidak Listing di Bursa Efek Indonesia.

Sehingga penelitian ini memobilisasi data berdasarkan variabel-variable yang diamati, antara lain:

Variabel $X_{1}$ yang diproksikan dengan rasio CAR merupakan Aset yang baik berupa barang-barang atau dana yang di jadikan sebagai pokok menjalankan sebuah usaha atau bisnis. Itu artinya jika kita bisa mengatur dana modal dengan baik, maka kita juga akan mampu membangun usaha lebih baik, karena sejatinya modal adalah pondasi dalam menjalankan usaha.

\section{Risiko $\left(\mathrm{X}_{2}\right)$}

Variabel bebas yang kedua yaitu risiko. Menurut definisi dari Prof. Dr. Ir. Soemarno, M.S, risiko adalah suatu kondisi yang timbul karena 
ketidakpastian dengan seluruh konsekuensi tidak menguntungkan yang mungkin terjadi.

\section{Variabel Terikat / (Dependent variabel) (Y)}

Variabel terikat dalam penelitian ini adalah kinerja keuangan Bank Muamalat Indonesia.

Analisis regresi linier berganda digunakan untuk mengetahui suatu hubungan fungsional antara variabel Y (dependent variable)dengan variabel $\mathrm{X}_{1}$ dan $\mathrm{X}_{2}$ (independent variable) atau bisa dinyatakan dalam sebuah persamaan:

$$
Y=a+b 1 X 1+b 2 X 2+e
$$

Dimana:

$$
\begin{aligned}
& \mathrm{Y}=\text { Kinerja Keuangan } \\
& \mathrm{a}=\text { Konstansta } \\
& \mathrm{X} 1=\text { Modal } \\
& \mathrm{X} 2=\text { Risiko } \\
& \mathrm{e} \quad=\text { Kekeliruan (Error) }
\end{aligned}
$$

\section{HASIL DAN PEMBAHASAN}

\begin{tabular}{|c|c|c|c|c|}
\hline No. & Tahun & Triwulan & Total Modal & Rata-rata \\
\hline 1 & \multirow{4}{*}{2013} & Pertama & Rp4,041,142 & \multirow{4}{*}{$\begin{array}{l}\text { Rp4,724,5 } \\
24\end{array}$} \\
\hline 2 & & Kedua & Rp4,434,768 & \\
\hline 3 & & Ketiga & Rp4,439,483 & \\
\hline 4 & & Keempat & Rp5,982,702 & \\
\hline 5 & \multirow{4}{*}{2014} & Pertama & Rp6,368,770 & \multirow{4}{*}{$\begin{array}{l}\text { Rp6,167,8 } \\
17\end{array}$} \\
\hline 6 & & Kedua & Rp6,411,317 & \\
\hline 7 & & Ketiga & Rp6,014,624 & \\
\hline 8 & & Keempat & Rp5,876,558 & \\
\hline 9 & \multirow{4}{*}{2015} & Pertama & Rp5,900,250 & \multirow{4}{*}{$\begin{array}{l}\text { Rp5,805,7 } \\
51\end{array}$} \\
\hline 10 & & Kedua & Rp6,055,037 & \\
\hline 11 & & Ketiga & Rp6,095,372 & \\
\hline 12 & & Keempat & Rp5,172,344 & \\
\hline 13 & \multirow{4}{*}{2016} & Pertama & Rp4,900,356 & \multirow{4}{*}{$\begin{array}{l}\text { Rp5,157,4 } \\
37\end{array}$} \\
\hline 14 & & Kedua & Rp5,251,211 & \\
\hline 15 & & Ketiga & Rp5,258,048 & \\
\hline 16 & & Keempat & Rp5,220,131 & \\
\hline 17 & \multirow{4}{*}{2017} & Pertama & Rp5,205,575 & \multirow{4}{*}{$\begin{array}{l}\text { Rp5 } 483,7 \\
42\end{array}$} \\
\hline 18 & & Kedua & Rp5,622,168 & \\
\hline 19 & & Ketiga & Rp4,979,813 & \\
\hline 20 & & Keempat & Rp6,127,412 & \\
\hline
\end{tabular}

Untuk dapat mengetahui perbedaan secara

\begin{tabular}{|c|c|c|c|c|}
\hline 21 & \multirow{4}{*}{2018} & Pertama & $\mathrm{Rp} 4,389,430$ & \multirow{4}{*}{$\begin{array}{l}\text { Rp4,729,9 } \\
99\end{array}$} \\
\hline 22 & & Kedua & Rp5,948,026 & \\
\hline 23 & & Ketiga & Rp4,327,533 & \\
\hline 24 & & Keempat & Rp4,255,006 & \\
\hline 25 & \multirow{4}{*}{2019} & Pertama & $\mathrm{Rp} 4,211,083$ & \multirow{4}{*}{$\begin{array}{l}\text { Rp3,792,8 } \\
09\end{array}$} \\
\hline 26 & & Kedua & Rp3,894,018 & \\
\hline 27 & & Ketiga & Rp3,914,792 & \\
\hline 28 & & Keempat & Rp3,871,341 & \\
\hline 29 & \multirow{2}{*}{2020} & Pertama & Rp3,708,035 & \multirow{2}{*}{$\begin{array}{l}\text { Rp3,683,6 } \\
88\end{array}$} \\
\hline 30 & & Kedua & Rp3,659,341 & \\
\hline
\end{tabular}
signifikan pada setiap tahunnya, pada tabel data berikut memaparkan perolehan modal yang dimiliki Bank Muamalat Indonesia dari tahun 2014 sampai tahun 2020 triwulan kedua.
Sumber: Laporan KPPM Tahun 2013-2020 PT Bank Muamalat Indonesia Tbk

Berdasarkan data laporan triwulanan yang sudah diolah, modal dari tahun 2013 sampai tahun 2020 triwulan pertama, modal Bank Muamalat Indonesia mengalami penurunan pada tiap periode

\begin{tabular}{|c|c|c|c|c|c|}
\hline No & Tahun & Triwulan & $\begin{array}{c}\text { CAR } \\
\left(X_{1}\right) \\
\% \\
\end{array}$ & $\begin{array}{c}\text { BOPO } \\
\left(X_{2}\right) \\
\% \\
\end{array}$ & $\begin{array}{c}\text { ROA } \\
\text { (Y) } \\
\%\end{array}$ \\
\hline 1. & \multirow{4}{*}{2013} & Pertama & 12.05 & 82.07 & 1.72 \\
\hline 2. & & Kedua & 13.50 & 82.79 & 1.66 \\
\hline 3. & & Ketiga & 12.85 & 82.67 & 1.68 \\
\hline 4. & & Keempat & 17.41 & 85.12 & 1.37 \\
\hline 5. & \multirow{4}{*}{2014} & Pertama & 17,61 & 85.55 & 1.44 \\
\hline 6. & & Kedua & 16.31 & 89.11 & 1.03 \\
\hline 7. & & Ketiga & 14.71 & 98.32 & 0.10 \\
\hline 8. & & Keempat & 14.15 & 97.33 & 0.17 \\
\hline 9. & \multirow{4}{*}{2015} & Pertama & 14.57 & 93.37 & 0.62 \\
\hline 10. & & Kedua & 13.60 & 94.84 & 0.51 \\
\hline 11. & & Ketiga & 13.71 & 96.26 & 0.36 \\
\hline 12. & & Keempat & 12.36 & 97.41 & 0.20 \\
\hline 13. & \multirow{4}{*}{2016} & Pertama & 12.10 & 97.32 & 0.25 \\
\hline 14. & & Kedua & 12.78 & 99.90 & 0.15 \\
\hline 15. & & Ketiga & 12.75 & 98.89 & 0.13 \\
\hline 16. & & Keempat & 12.74 & 97.76 & 0.22 \\
\hline 17. & \multirow{4}{*}{2017} & Pertama & 12.83 & 98.19 & 0.12 \\
\hline 18. & & Kedua & 12.94 & 97.40 & 0.15 \\
\hline 19. & & Ketiga & 11.58 & 98.10 & 0.11 \\
\hline 20. & & Keempat & 13.62 & 97.68 & 0.11 \\
\hline 21. & \multirow{2}{*}{2018} & Pertama & 10.16 & 98.03 & 0.15 \\
\hline 22. & & Kedua & 15.92 & 92.78 & 0.49 \\
\hline
\end{tabular}
nya. Hal ini terjadi akibat adanya penurunan terhadap Instrumen modal dalam bentuk saham atau lainnya yang memenuhi persyaratan tertentu, dan faktor lainnya seperti kerugian tahun-tahun lalu serta faktor pengurang dari modal inti. 


\begin{tabular}{|l|l|l|l|l|l|}
\hline 23. & & Ketiga & 12.12 & 94.38 & 0.35 \\
\cline { 4 - 6 } 24. & & Keempat & 12.34 & 98.24 & 0.08 \\
\hline 25. & \multirow{4}{*}{2019} & Pertama & 12.58 & 99.13 & 0.02 \\
\cline { 4 - 6 } & & Kedua & 12.01 & 99.04 & 0.02 \\
\cline { 4 - 6 } 26. & Ketiga & 12.42 & 98.83 & 0.02 \\
\hline 27. & & Keempat & 12.42 & 99.50 & 0.05 \\
\hline 28. & \multirow{2nnyyy}{*}{2020} & Pertama & 12.12 & 87.94 & 0.03 \\
\cline { 4 - 6 } 29. & & Kedua & 12.13 & 98.19 & 0.03 \\
\hline 30. & & &
\end{tabular}

Sumber : Laporan rasio keuangan 2013-2020 PT Bank Muamalat Indonesia Tbk

Tabel di atas merupakan data sekunder yang telah diolah terkait dengan variabel-variabel dalam penelitian. Rasio CAR dan BOPO merupakan variabel bebas, dimana CAR (\%) sebagai $\mathrm{X}_{1}$ dan BOPO (\%) sebagai $\mathrm{X}_{2}$. Sedangkan rasio ROA (\%) merupakan variabel terikat, atau diuji sebagai $\mathrm{Y}$. Ketiga variabel ini akan digunakan dalam penelitian untuk mengetahui apakah variabel independen yang disebutkan memiliki pengaruh terhadap variabel dependen atau tidak.

Tabel di atas merupakan hasil output uji statistik deskriptif yang mana menunjukan variabel independen capital adequacy ratio (CAR) mempunyai nilai minimum sebesar $10,16 \%$ dan nilai maksimum sebesar 17,61 \%. Sementara nilai standar deviasi sebesar 1,69232 \% dan nilai rata-rata sebesar 13,2797 $\%$. Variabel independen beban operasional terhadap pendapatan operasional (BOPO) mempunyai nilai minumum sebesar $82.07 \%$ dan nilai maksimum sebesar $99,90 \%$. Sementara nilai standar deviasi sebesar 5,71813 \% dan nilai rata-rata sebesar 94,5380 $\%$. Variabel dependen return of aset (ROA) mempunyai nilai minimum sebesar $0,02 \%$ dan nilai maksimum sebesar $1,72 \%$. Sementara nilai standar deviasi $0.55947 \%$ dan nilai rata rata sebesar 0,4447 $\%$.

\begin{tabular}{|c|c|c|c|c|}
\hline \multicolumn{5}{|c|}{ Model Summary $^{\mathbf{b}}$} \\
\hline Model & $\mathrm{R}$ & $\begin{array}{c}\mathrm{R} \\
\text { Square }\end{array}$ & $\begin{array}{c}\text { Adjusted } \\
\text { R Square }\end{array}$ & $\begin{array}{c}\text { Std. } \\
\text { Error of } \\
\text { the } \\
\text { Estimate }\end{array}$ \\
\hline 1 & $.932^{\mathrm{a}}$ & .869 & .859 & .20988 \\
\hline \multicolumn{2}{|l|}{ a. Predictors: (Constant), BOPO, CAR } \\
\hline \multicolumn{2}{|l|}{ b. Dependent Variable: ROA } \\
\hline
\end{tabular}

Berdasarkan hasil output di atas, dijelaskan bahwa besarnya nilai koefisien atau hubungan (R) adalah sebesar 0.932. Dan didapatkan nilai Adjusted R Square (koefisien determinasi) sebesar 0,869 yang artinya pengaruh variabel independen $(X)$ terhadap variabel dependen $(\mathrm{Y})$ sebesar $86.9 \%$, sedangkan sisanya 13,1 \% dipengaruhi oleh variabel lain di luar penelitian ini.

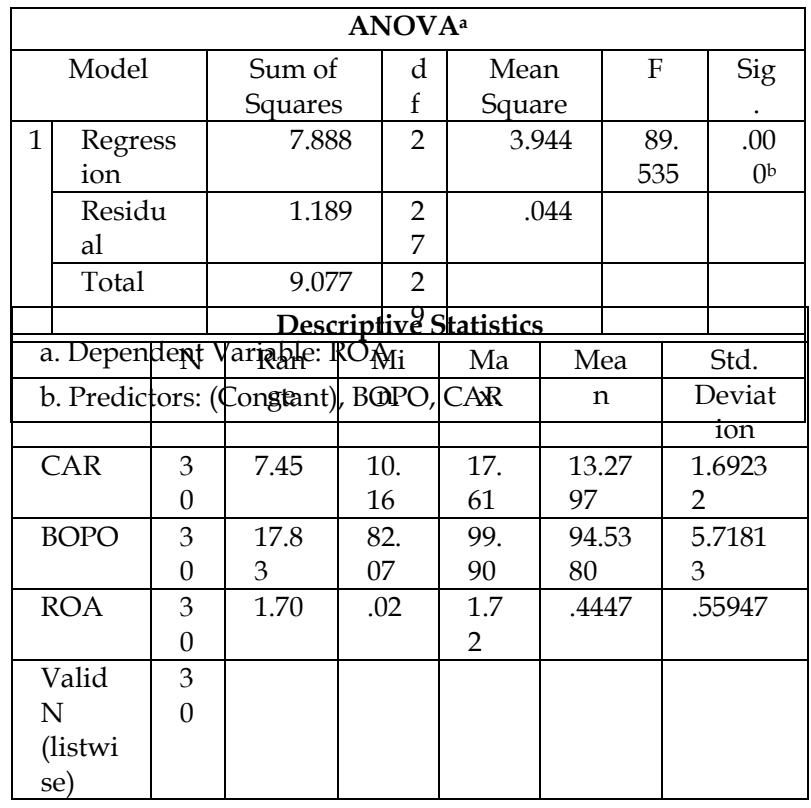

Tabel di atas menunjukan nilai probaility value dari model regresi yang digunakan dalam penelitian lebih kecil dari tingkat signifikansi 0,05 (5\%) yaitu sebesar 0,000 dan nilai $F$ hitung 89,535 atau > F tabel 3.34, sehingga dapat disimpulkan bahwa hasil uji signifikasi simultan atau Uji $\mathrm{F}$ terdapat pengaruh variabel $X_{1}$ dab $X_{2}$ secara simultan terhadap $Y$. 


\begin{tabular}{|c|c|c|c|c|c|c|}
\hline \multicolumn{7}{|c|}{ Coefficients $^{a}$} \\
\hline & \multirow{2}{*}{ Model } & \multicolumn{2}{|c|}{$\begin{array}{l}\text { Unstandardi } \\
\text { zed } \\
\text { Coefficients }\end{array}$} & \multirow{2}{*}{$\begin{array}{c}\begin{array}{c}\text { Std. } \\
\text { Coeffici } \\
\text { ents }\end{array} \\
\text { Beta }\end{array}$} & \multirow{2}{*}{$\mathrm{t}$} & \multirow{2}{*}{$\begin{array}{l}\text { Si } \\
\text { g. }\end{array}$} \\
\hline & & B & $\begin{array}{l}\text { Std. } \\
\text { Erro } \\
\mathrm{r}\end{array}$ & & & \\
\hline \multirow[t]{3}{*}{1} & $\begin{array}{l}\text { (Const } \\
\text { ant) }\end{array}$ & $\begin{array}{r}8.2 \\
51\end{array}$ & 916. & & $\begin{array}{r}9.00 \\
8\end{array}$ & $\begin{array}{r}.0 \\
00\end{array}$ \\
\hline & $\begin{array}{l}\text { CAR \% } \\
(\mathrm{X} 1)\end{array}$ & $\begin{array}{r}.23 \\
9 \\
\end{array}$ & .026. & .493. & $\begin{array}{r}3.20 \\
3 \\
\end{array}$ & $\begin{array}{r}.0 \\
01 \\
\end{array}$ \\
\hline & $\begin{array}{l}\text { BOPO } \\
\%(\mathrm{X} 2)\end{array}$ & $\begin{array}{r}.08 \\
7\end{array}$ & .008 & -.888 & $\begin{array}{r}- \\
11.4 \\
86\end{array}$ & $\begin{array}{r}.0 \\
02\end{array}$ \\
\hline
\end{tabular}

Dari hasil uji t yang telah dilakukan, diperoleh nilai sig. masing-masing variabel independen, dimana nilai signifikasi CAR $\left(\mathrm{X}_{1}\right)$ sebesar 0.001 atau $<0.05$ dan nilai $t$ hitung $3.203>2.052$, sehingga dapat disimpulkan bahwa variabel $X_{1}$ berpengaruh terhadap Y. Selanjutnya pada nilai signifikasi BOPO $\left(\mathrm{X}_{2}\right)$ sebesar 0.002 atau $<0.05$ dan nilai $t$ hitung $11.486>2.052$, sehingga dapat disimpulkan bahwa variabel $\mathrm{X}_{2}$ berpengaruh terhadap $\mathrm{Y}$. Maka dapat kita ketahui persamaan regresi linear berganda dalam penelitian ini sebagai berikut:

$$
\mathrm{ROA}=8,251+0,239 \mathrm{X}_{1}-0,087 \mathrm{X}_{2}+\varepsilon
$$

Hasil uji t di atas akan dijelaskan sebagai berikut:

Pengaruh Capital Adequacy Ratio (CAR) terhadap Return On Assets (ROA)

Uji statistik $\mathrm{t}$ bernilai positif dengan Sig. sebesar 0,001 lebih kecil dari tingkat signifikansi $a=5 \%$ sehingga dapat disimpulkan bahwa CAR berpengaruh positif dan signifikan terhadap ROA. Dengan demikian H1 yang menyatakan bahwa Capital Adequacy Ratio (CAR) berpengaruh terhadap Return On Assets (ROA) diterima.

\section{Pengaruh Beban Operasional Pendapatan Operasional (BOPO) terhadap Return on Assets (ROA)}

Uji statistik $\mathrm{t}$ bernilai negatif dengan Sig. sebesar 0,002 yang lebih kecil dari tingkat signifikansi $\alpha=$
5\% sehingga dapat disimpulkan bahwa BOPO berpengaruh negatif dan signifikan terhadap ROA. Sehingga dengan demikian $\mathrm{H} 2$ yang menyatakan bahwa Beban Operasional Pendapatan Operasional (BOPO) berpengaruh terhadap Return on Assets (ROA) diterima.

\section{Besarnya Pengaruh Modal dan Risiko Terhadap} Kinerja Keuangan Bank Muamalat Indonesia

Secara keseluruhan modal dan risiko berpengaruh signifikan terhadap Kinerja Keuangan. Dengan nilai signifikansi modal sebesar 0.001 dan risiko sebesar 0.002. Berdasarkan hasil ouput uji SPSS tersebut maka dapat di artikan bahwa modal memiliki pengaruh lebih besar terhadap kinerja keuangan Bank Muamalat Indonesia pada periode masa penelitian tahun 2013-2020. Hal ini dikarenakan modal memiliki nilai signifikasi lebih kecil dari pada risiko.

\section{KESIMPULAN}

Dari hasil penelitian yang telah diamati serta dilaksanakan oleh peneliti guna menganalisis bagaimana pengaruh modal (CAR) dan pengaruh risiko (BOPO) terhadap kinerja keuangan (ROA) Bank Muamalat Indonesia. Melalui hasil analisis regresi berganda, maka didapati kesimpulan dari penelitian ini adalah sebagai berikut:

- Secara Parsial Modal (CAR) berpengaruh langsung terhadap Kinerja Keuangan (ROA). Dimana berdasarkan hasil uji analisis uji regresi secara parsial variabel CAR memiliki pengaruh positif terhadap ROA Bank Muamalat Indonesia. Hal ini berarti jika semakin tinggi modal yang dimiliki Bank Muamalat Indonesia, maka akan semakin meningkat pula kinerja keuangan Bank Muamalat Indonesia. Hal sama dengan Risiko yang (BOPO) yang berengaruh 
langsung terhadap Kinerja keuangan Bank Muamalat Indonesia. Berdasarkan hasil uji analisis uji regresi secara parsial variabel BOPO memiliki pengaruh negatif terhadap ROA Bank Muamalat Indonesia. Hal ini berarti jika semakin rendah risiko operasional yang ditanggung Bank Muamalat Indonesia, maka akan semakin tinggi kinerja keuangan Bank Muamalat Indonesia, begitu sebaliknya.

- Secara Simultan Modal dan Risiko secara bersama-sama berpengaruh terhadap Kinerja Keuangan Bank Muamalat Indonesia pada pengujian sampel dari tahun 2013 sampai 2020.

\section{REFERENCES}

Antonio, Syafii. (1990). Bank Syari'ah. Jakarta: Tazkie Institute. Hal. 25

Antonio, Syafii. (2006). Dasar-Dasar Manajemen Bank Syariah. Jakarta: Pustaka Alfabeta. Hal. 2.

Darmawi, Herman. (2006). Manajemen Risiko. Jakarta: PT. Bumi Aksara.

Idroes, Ferry. (2008). Manajemen Risiko Perbankan. Jakarta: PT. Raja Grafindo Persada.

Fahmi, Irham. (2013). Manajemen Risiko. Bandung: Alfabeta.

Majid, M. S. (2014). Regulasi Perbakan Syariah : Studi Komparatif Antara Malaysia Dan Indonesia, 235237.

Martono, N. (2019). Metode Penelitian Kuantitatif Analiis Data Isi dan Analisis Data Sekunder. Depok: Rajawali Pers.

Prasetyoningrum, Kristin. (2015). Risiko Bank Syariah. Yogyakarta: Pustaka Pelajar

Ghozali, Imam. (2013). Aplikasi Analisis Multivariete Dengan Program IBM SPSS 21. Semarang: Universitas Diponogoro.
Rusdin, M. (2006). Pasar Modal. Bandung: Alfabeta. Karim, Adiwarman A. (2010). Bank Islam: Analisis Fiqih dan Keuangan. Jakarta: PT. Rafa Grafindo Persada.

Kasmir. (2000). Manajemen Perbankan, Jakarta: PT.

Raja Grafimdo Persada.

Annisa, A. (2018). Analisis Pengaruh Risiko

Perbankan Terhadap Kinerja Keuangan.

Keuangan, hal. 2 dan 51.

Fathonah, Annisa, D. H. (2020). Estimasi Pengaruh

Faktor Internal Bank dan Stabilitas

Makroekonomi terhadap Profitabilitas dengan

Mediasi Rasio Pembiayaan Bermasalah di Bank Muamalat Indonesia. Jurnal Manajemen Syariah . Ariyani, D. (2010). Analisis Pengaruh CAR, FDR, BOPO dan NPF Terhadap Profitabilitas Bank Muamalat Indonesia Tbk , hal. 107-108

Astuti, M. (2012). Analisis Pengaruh Struktur Modal Terhadap Kinerja Keuangan Perusahaan (Studi Kasus pada Perbankan yang Terdaftar di Bursa Efek Indonesia periode, 28

Oktaviani, Dian. (2017). Pengaruh Pembiayaan Bermasalah, Tingkat, Likuiditas Dan Rasio Pembiayaan, Terhadap Profitabilitas Bank Syariah Mandiri Tahun 2012-2016. Jurnal Ekonomi Dan Perbankan Syariah .

Hutagalung, Esther Novelina. (2013). Analisis Rasio Keuangan Terhadap Kinerja Keuangan Bank Umum di Indonesia , hal. 123-125.

Faisol, A. (2007). Analisis Kinerja Keuangan Bank Pada PT. Bank Muamalat Indonesia Tbk. Bisnis dan Management, hal. 131-133.

Fauzan, M. (201). Faktor Yang Mempengaruhi Masyarakat Non Muslim Menjadi Nasabah Dengan Regresi Linear Berganda Di PT. Bank Muamalat Indonesia Cabang Pematangsiantar. 
Jurnal Riset Sistem Informasi dan Teknik Informatika.

Ginting, W. A. (2020). Pengaruh Rasio Lancar, Debt to Total Asset, Return on Investment di Perusahaan Consumer Goods yang terdaftar di Bursa Efek Indonesia Periode Tahun 20112017. Jurnal Ekonomi.

Hameeda, Hussain Abu. (2012). “Risk Management Practices of Conventional and Islamic Bank in Bahrain", The Journal of Risk Finance, Vol. 13 pp. hal. 215-239.

Masruroh, S. (2019). Pengaruh Risiko Pembiayaan, Risiko Pasar, Risiko Likiuditas dan Risiko Operasional Terhadap Kinerja Keuangan (ROA) Bank Umum Syariah Di Indonesia, hal. 6-7.

Matindas, A. M. (2015). Pengaruh Capital Adequacy Ratio (Car), Bopo Dan Non Performing Loan (Npl) Terhadap Kinerja Keuangan Perbankan Di Indonesia. Jurnal Riset Akuntasi.

Mawardi, W. (2004). Analisis Faktor Yang Mempengaruhi Kinerja Keuangan Bank Umum Di Indonesia . Jurnal Keuangan, hal. 13-16.

Bastomi, Muhamad. (2017). The Role of Corporate Governance and Risk Management on Banking. Jurnal Keuangan dan Perbankan, hal. 672-676.

Muklis, I. (2012). Kinerja Keuangan Bank dan Stabilitas Makroekonomi Terhadap Profitabilitas Bank Syariah Di Indonesia. Jurnal Keuangan dan Perbankan, hal. 280-284.

Prasetia, F. (2011). Pengukuran Efisiensi Perbankan Syariah Berbasis Manajemen Risiko. Jurnal Keuangan dan Perbankan, hal. 119-120.

Sandy, I. C. (2014). Analisis Pengaruh Struktur Modal Terhadap Kinerja Keuangan Pada Perbankan Di Indonesia. Keuangan, ha. 2, 7, 28-29.
Silvia, S. A. (2017). Pengaruh Kualitas Aset Terhadap Profitabilitas Pada Perbankan Syariah di Indonesia. Jurnal Ekonomi Islam.

Siswanto. (2008). Manajemen Bank: Konvensional dan Syariah. UIN Malang-Press (Anggota IKAPI).

Sunarjo, S. Y. (2017). Sistem Pengendalian Risiko Operasional Pada Bank. Jurnal keuangan dan Perbankan, hal. 97-100.

Sutrisno. (2017). Pengukuran Kesehatan Bank Syariah Dengan Sharia Complience dan Performance. Jurnal Keuangan dan Perbankan, hal. 134-141.

Thalib, D. (2016). Intermediasi Struktur Modal, Efisiensi, Permodalan dan Risiko Terhadap Profitabilitas Bank, hal. 126.

Wahyuni, S. (2018). Kinerja Keuangan Berbasis Shari'ate Value Added Keuangan Berbasis Shari'ate Value Added Sharia dan Unit Usaha Sharia di Indonesia. Jurnal Ilmiah Akuntansi.

Wijaya, C. (2015). Pengaruh Biaya Operasional Pendapatan Operasional (BOPO) Terhadap Return Of Assets (ROA) Pada Perusahaan Sub-Sektor Yang Terdaftar Di Bursa Efek Indonesia . Akuntansi, hal. 26-27.

Wijayani, D. R. (2017). Kepercayaan Masyarakat Menabung pada Bank Umum Syariah. Jurnal Ekonomi dan Perbankan Syariah .

Indonesia, B. (2020, Maret 30). Statistik Sistem Keuangan Indonesia. Retrieved from:https://www.bi.go.id/id/statistik/sski/ Pages/SSKI_Maret_2020.aspx Indonesia, B. M. (2020, Mei 15). Laporan Keuangan Bank Muamalat Indonesia. Retrieved from https://www.bankmuamalat.co.id/profilbank-muamalat 
Kemenag, Qur'an. (2020.). Dipetik April 4, 2020, dari https://quran.kemenag.go.id/

Keuangan, O. J. (2020, Juni 20). Laporan Publikasi Bank Muamalat Indonesia. Retrieved from Laporan Kuangan Perbankan: https://www.ojk.go.id/id/kanal/perbankan/ data-dan- statistik/laporan- keuanganperbankan/Default.aspx
Nasional, D. S. (2020, April 01). Fatwa DSN MUI. Retrieved from https://tafsirq.com/fatwa/dsnmui/pembiayaan-mudharabah-qiradh 